\title{
КОРЕКЦІЯ ПРОЯВІВ ДИСБАКТЕРІОЗУ КИШЕЧНИКА У ХВОРИХ НА АТОПІЧНИЙ ДЕРМАТИТ У ПРАКТИЦІ СІМЕЙНОГО ЛІКАРЯ
}

\author{
ФН. Р. Матковська, Л. М. Скрипник \\ ДВНЗ «Івано-Франківський національний медичний університет»
}

РЕЗЮМЕ. Метою дослідження було виявлення проявів дисбактеріозу (ДБ) товстого кишечника у хворих на АД під впливом препарату «Біосім'я».

Обстежено і проліковано 84 хворих на атопічний дерматит (АД). Таким пацієнтам на фоні базового лікування призначали препарат «Біосім'я» у дозі 1 флакон двічі на день впродовж 1 міс. Клінічно у всіх хворих з ПТК спостерігали здуття живота, порушення випорожнення, у 82,8 \% пацієнтів - алергічні реакції. Дослідження крові показало підвищення еозинофілів і рівня IgE відповідно в 1,5-2 та 2-3 рази. При бактеріологічному дослідженні калу виявлено значне зниження кількості нормальної кишкової мікрофлори. В 55,2 \% пацієнтів спостерігався ріст умовно-патогенної мікрофлори. Через 1 тиждень після лікування відмітили зменшення проявів АД, супутніх алергічних реакцій та розладів кишечника у 82,8 \%, а у 17,2 \% - їх зникнення, через 2 тижні прояви зникли ще у 72,4 \%. Показники ЗАК та ІА у них нормалізувались. Через місяць проявів АД та кишкових розладів не виявлено у жодного пацієнта. Необхідно відмітити, що через 2 тиж. лікування у хворих без ПТК прояви АД зникли у 65,4 \% осіб.

КлючОВІ слОВА: атопічний дерматит; дисбактеріоз; сімейний лікар.

Вступ. Актуальність проблеми атопічного дерматиту (АД) зумовлена продовженням зростання кількості хворих з цією патологією. Особливо це стосується лікарів первинної ланки медикосанітарної допомоги, оскільки пацієнти вперше звертаються саме до сімейного лікаря. При АД частим проявом $\epsilon$ харчова алергія, що супроводжується дисбіотичними змінами кишкового мікробіоценозу.

Основна частина. Метою дослідження було виявлення проявів дисбактеріозу (ДБ) товстого кишечника у хворих на АД та впливу препарату «Біосім'я" на перебіг захворювання.

Обстежено і проліковано 84 хворих на АД. Усім хворим проведено бактеріологічне дослідження кишкової мікрофлори, загальний (ЗАК) та імунологічний аналіз (IA) крові. У 58 осіб виявлено порушення з боку товстого кишечника (ПТК). Серед них було $67,2 \%$ чоловіків та 32,8 \% жінок, середній вік $(25,3 \pm 5,8)$ років. Таким пацієнтам на фоні базового лікування призначали препарат «Біосім'я» у дозі 1 флакон двічі на день впродовж 1 міс.

\section{ЛІТЕРАТУРА}

1. Діагностика та терапія атопічного дерматиту (стандарти діагностики та терапії) / В. В. Бережний і [співавт.]. - Київ, 2002. - 32 с.

2. Галлямова Ю. А. Атопический дерматит и дисбактериоз / Ю. А. Галлямова // Лечащий врач. - 2010. - № 10. - С. 14-16.

3. Калюжная Л. Д. Актуальная проблема дермато-
Клінічно у всіх хворих з ПТК спостерігали здуття живота, порушення випорожнення (проноси або закрепи), у 82,8 \% пацієнтів - алергічні реакції (поліноз, харчова алергія). Дослідження крові показало підвищення еозинофілів і рівня IgE відповідно в 1,5-2 та 2-3 рази. При бактеріологічному дослідженні калу виявлено значне зниження кількості нормальної кишкової мікрофлори. В 55,2 \% пацієнтів спостерігався ріст умовно-патогенної мікрофлори. Через 1 тиждень після лікування відмічено зменшення проявів АД, супутніх алергічних реакцій та розладів кишечника у $82,8 \%$, а у $17,2 \%$-їх зникнення. Через 2 тижні прояви зникли ще у 72,4 \%. Показники ЗАК та IA у них нормалізувались. Через місяць проявів АД та кишкових розладів не виявлено у жодного пацієнта. Необхідно відмітити, що через 2 тиж. лікування у хворих без ПТК прояви АД зникли у $65,4 \%$ осіб.

Висновки. Для зменшення проявів ДБ у хворих на АД рекомендовано використовувати препарат «Біосім'я».

венерологии - атопический дерматит / Л. Д. Калюжная // Здоров'я України. - 2016. - № 18 (391). - С. 67-68.

4. Наказ МОЗ України від 04.07.2016 № 670 «Про затвердження та впровадження медико-технологічних документів зі стандартизації медичної допомоги при атопічному дерматиті» [Електронний ресурс]. - Режим доступу: // moz.gov.ua. 
Огляди літератури, оригінальні дослідження, погляд на проблему, короткі повідомлення

\section{REFERENCES}

1. Berezhnyi, V.V. (2002). Diahnostyka ta terapiia atopichnoho dermatytu (standarty diahnostyky ta terapii) [Diagnosis and treatment of atopic dermatitis (standards for diagnosis and therapy)]. Kyiv [in Ukrainian].

2. Gallyamova, Yu.A. (2010). Atopicheskiy dermatit i disbakterioz [Atopic dermatitis and dysbacteriosis]. Lechashchiy vrach - Attending Physician, 10, 14-16 [in Russian].

3. Kalyuzhnaya, L.D. (2016). Aktualnaya problema dermatovenerologii - atopicheskiy dermatit [The actual problem of dermatovenereology is atopic dermatitis]. Zdorovia Ukrainy - Health of Ukraine, 18 (391), 67-68.

4. Nakaz MOZ Ukrayiny vid 04.07.2016 № 670 «Pro zatverdzhennia ta vprovadzhennia medykotekhnolohichnykh dokumentiv zi standartyzatsii medychnoyi dopomohy pry atopichnomu dermatyti» [MOH Ukraine from 04.07.2016 number 670 «On approval and introduction of medical and technological documents on standardization of care in atopic dermatitis»] [Electronic resource]. Retrieved from: // moz.gov.ua.

\title{
КОРРЕКЦИЯ ПРОЯВЛЕНИЙ ДИСБАКТЕРИОЗА КИШЕЧНИКА У БОЛЬНЫХ АТОПИЧЕСКИМ ДЕРМАТИТОМ В ПРАКТИКЕ СЕМЕЙНОГО ВРАЧА
}

○Н. Г. Матковская, Л. Н. Скрипник

\author{
ДВНЗ «Ивано-Франковский национальный медицинский университет»
}

РЕЗЮМЕ. Целью исследования было выявление проявлений дисбактериоза (ДБ) толстого кишечника у больных АД под влиянием препарата «Биосемья».

Обследовано и пролечено 84 больных атопическим дерматитом (АД). Таким пациентам на фоне базового лечения назначали препарат «Биосемья» в дозе 1 флакон дважды в день в течение 1 мес. Клинически у всех больных с ПТК наблюдали вздутие живота, нарушение испражнений, у 82,8 \% пациентов - аллергические реакции. Исследование крови показало повышение эозинофилов и уровня IgЕ соответственно в 1,5-2 и 2-3 раза. При бактериологическом исследовании кала выявлено значительное снижение количества нормальной кишечной микрофлоры. У 55,2 \% пациентов наблюдался рост условно-патогенной микрофлоры. Через 1 неделю после лечения отметили уменьшение проявлений АД, сопутствующих аллергических реакций и расстройств кишечника у 82,8 \%, а у 17,2 \% - их исчезновение, через 2 недели проявления исчезли еще у 72,4 \%. Показатели ОАК и ИА у них нормализовались. Через месяц проявления АД и кишечных расстройств не выявлено ни у одного пациента. Необходимо отметить, что через 2 нед. лечения у больных без ПТК проявления АД исчезли у 65,4 \% человек.

КЛЮЧЕВЫЕ СЛОВА: атопический дерматит; дисбактериоз; семейный врач.

\section{CORRECTION OF MANIFESTATIONS OF INTESTINAL DYSBIOSIS IN PATIENTS WITH ATOPIC DERMATITIS IN FAMILY DOCTOR PRACTICE}

@N. R. Matkovskaya, L. N. Skrypnyk

\section{Ivano-Frankivsk National Medical University}

SUMMARY. The aim of the study was to identify manifestations of dysbiosis (DB) of the colon in patients with AD under the influence of the drug "Biosimia."

84 patients with atopic dermatitis (AD) were examined and treated. Such patients on the background of basic treatment were administered with drug "Biosimia" at a dose of 1 bottle twice a day for 1 month. Clinically, all patients with PTC watched bloating, bowel movements abuse in $82.8 \%$ of patients - allergic reactions. Research showed increasing blood levels of eosinophils and $\mathrm{lgE}$, respectively $1.5-2$ and $2-3$. When bacteriological study of feces revealed a significant decrease in the number of normal intestinal microflora. In $55.2 \%$ of patients experienced growth of pathogenic microorganisms. After 1 week of treatment noted a decrease manifestations of $A D$, associated allergic reactions and intestinal disorders in $82.8 \%$ and $17.2 \%$ - their disappearance after 2 weeks are signs disappeared in $72.4 \%$. KLA indicators and EAs they normalized. A month later manifestations of AD and intestinal disorders detected in any patient. It should be noted that after 2 weeks. treatment in patients without AD CD displays disappeared in $65.4 \%$ of subjects.

KEY WORDS: atopic dermatitis; overgrowth; family doctor. 